\title{
Sol maksiller sinüste izole Aspergillus enfeksiyonu: olgu bildirimi
}

\author{
Benay Yıldırım, Alaa Mohamed Shuibat* \\ Oral Patoloji Anabilim Dalı, Gazi Üniversitesi Diş Hekimliği \\ Fakültesi, Ankara, Türkiye
}

\section{ÖZET}

TANITIM: Paranazal sinüslerin aspergillozis durumu çoğunlukla immün sistemi baskılanmış hastalarda meydana gelen seyrek görülen fırsatçı bir enfeksiyondur. Aspergillus kaynaklı paranazal sinüs enfeksiyonlarında Aspergillus fumigatus en sık görülen türdür.

OLGu BiLdiRimi: Bu olgu sunumunda tükürük bezinde mevcut adenokarsinom nedeniyle kemoterapi tedavisi almış olan hastanın sol maksiller sinüsünde gelişen aspergillozis olgusu sunulmaktadır. Yoğun ağrı atakları şikayetiyle başvuran hastanın yapılan klinik muayenesinde herhangi bir belirgin ağrı kaynağı saptanamamıştır. Hastadan alınan panoramik radyografinin incelemesinde, sol maksiller sinüs içerisinde radyoopak ve sınırları iyi seçilemeyen, kırık bir köke benzeyen parça izlenmiştir. Lokal anestezi altında kırık kök ile enfekte dokular Caldwell-Luc operasyonu ile alınarak Oral Patoloji Anabilim Dalına histopatolojik inceleme için gönderilmis ve vakaya aspergillozis tanısı konulmuştur. Operasyon sonrası hastaya iki hafta süreli vorikonazol tedavisi uygulanmıştır (100 $\mathrm{mg}, 2 \times 1$, peroral). Bu tedaviyi takiben 3 aylık periodlarla, toplam 6 ay boyunca yapılan kontrol muayenelerinde aspergillozis ile ilgili bulguya rastlanmamıştır.

Sonuç: Kronik sinüzit ile benzerlikler gösteren aspergillozis olgusuna dikkatli yaklaşılması ve gerekli görüldüğünde paranazal sinüslerden alınan dokuların patolojik incelemesinin yapılması önerilmektedir.

Anahtar Kelimeler: Aspergillozis; maksiller sinüs; mantar hastalıkları; paranazal sinüs hastalıkları

Kaynak Göstermek İçin: Yıldırım B, Shuibat AM. Sol maksiller sinüste izole Aspergillus enfeksiyonu: olgu bildirimi. Acta Odontol Turc 2014;31(2):99-101.

[Abstract in English is at the end of the manuscript]

\section{Giriş}

Aspergillus, dünyanın her yerinde rastlanabilen bir mantar grubudur. Özellikle kuzey yarımkürede sonbahar ve

Makale gönderiliş tarihi: 07 Şubat 2013; Yayına kabul tarihi: 21 Ağustos 2013 *iletişim: Alaa Mohamed Shuibat, Oral Patoloji Anabilim Dalı, Gazi Üniversitesi Diş Hekimliği Fakültesi, 8. Cadde 82. Sokak, 06510, Emek, Ankara, Türkiye; e-posta: shebatala@yahoo.com kış aylarında daha sık izlenir. Aspergilluslar spor ile üreyen filament şeklinde mantar sınıfındadırlar ve pek azı insanlar için patojen kabul edilmektedir. ${ }^{1}$ Çeşme suyunda, toprakta, çürümüş sebze ve bitkilerde, Islak boyada, yiyecek, toz ve hatta hastanelerde kullanılan tıbbi ajanlar ve gereçlerde dahi bulunabilen Aspergillus'un kişiden kişiye bulaşması söz konusu değildir. ${ }^{1-3}$ Her nekadar sporlar insanlar tarafından solunabiliyor olsa da, aspergillozis enfeksiyonu için çok miktarda spor solunması ve aynı zamanda yoğun bir immün baskılanmanın eşlik etmesi gerektiğinden, klinik hastalık sayısı oldukça azdır. $^{3}$

Aspergillus'un sebep olduğu hastalıklara aspergillozis denir. Kadınlarda erkeklere göre üç-kat sıklıkla izlenmektedir ve genellikle orta yaşlarda ortaya çıkmaktadır. Aspergillozis tablosunun seyri birçok faktör tarafından belirleniyor olmasına rağmen tüm bu etkenlerin içerisinde en önemlisi hastanın immün durumudur. . $^{3,4}$

Aspergillozis sıklıkla antibiyotiklerin, kortikosteroidlerin, sitostatiklerin yoğun kullanımıyla ilişkilendirilmektedir. Çenelerin boşluklarında görülen aspergillozis ise tedavi görmemiş bir dişin pulpasının gangrenöz inflamasyonundan kaynaklanabileceği gibi üst çenede yer alan ve kökleri sinüslere açılan dişlere uygulanan endodontik tedaviler ve implant yerleştirilmesi sonrasında da ortaya çıkabilmektedir. ${ }^{4-6}$

Aspergillus'un oluşturduğu hastalıklar allerjik reaksiyonlardan ölümcül sistemik enfeksiyonlara kadar uzanan geniş bir yelpazede değişkenlik gösterir. Aspergillus klinik olarak üç farklı şekilde ortaya çıkabilir: allerjik sinüzit, fungus topu veya invaziv aspergillozis. Allerjik hastalık genellikle akıntılı, tıkanık burun ile karakterlidir ve nasal poliplere sebebiyet verebilir. ${ }^{3,4}$ Aspergillozis tedavi edilmediği takdirde kafatası içerisinde ilerleme gösterir. Komşu dokunun doğrudan invazyonu çok seyrek gerçekleşebildiğinden bu yayılma hemen her seferinde hematojen yolla gerçekleşir. Kafatası içerisindeki odaklara yayılımı söz konusu olduğunda aspergillozisin prognozu oldukça kötüdür. Kafa içi aspergillozis trombüs veya enfarktüs oluşumu ya da arteritis oluşumu sonrasında damar duvarının yırtılması sonucunda ölümle sonuçlanabilmektedir. ${ }^{4-7}$ 
Tedavi yaklaşımında cerrahi drenajın yanısıra poliplerin çıkartılması, bakteriyel enfeksiyonun eliminasyonu, lokal veya kısa süreli oral steroid ve antifungal ilaçların kullanımı yer almaktadır. ${ }^{6,8}$

\section{Olgu Bildirimi}

Kırkaltı yaşında kadın hasta Gazi Üniversitesi Diş Hekimliği Fakültesine sol posterior maksillada, sol alt göz kapağında ve orbita tabanında yoğun ağıı atakları şikayeti ile başvurmuştur. Klinik ekstraoral muayenede ekspansiyon veya asimetri gözlenmemiştir. İntraoral muayenede bası ile hassasiyet oluşmamış, yumuşak dokularda ödem veya fistül ağzı saptanmamış ve olası herhangi bir ağrı kaynağı belirlenmemiştir. Hastadan alınan panoramik radyografinin incelenmesinde sol maksiller sinüs içerisinde radyoopak ve sınırları iyi seçilemeyen, kırık köke ait olduğu düşünülen parça izlenmiştir (Resim 1). Hasta üst sol büyük azı dişlerinin 15 sene önce çekilmiş olduğunu, ancak herhangi bir kök kırığı olgusu hatırlamadığını belirtmiştir. İlerleyen tıbbi anemnezde hastanın sol submandibuler tükürük bezine ait infiltratif duktal adenokarsinom tanısı aldığı öğrenilmiştir. Hasta bu olgu sebebiyle aldığı kemoterapi ve radyoterapinin, kliniğe başvurusundan 6 ay önce sonlandığını bildirmiştir. Sağ maksiller sinüs klinik ya da radyografik olarak herhangi bir patoloji içermemekteydi.

Hastanın aydınlatıımış onamı temin edildikten sonra Caldwell-Luc yöntemi ile sinüs boşluğundaki enfekte sinüs mukozası ve kırık kök alınıp histopatolojik incelemeye gönderilmiştir. Makroskopik olarak nekrotik dokudan oluştuğu düşünülen materyalin histopatolojik değerlendirmesinde amorf görünümlü nekrotik dokular komşuluğunda yaygın Aspergillus hifleri izlenmiştir. Hiflerin gövde ve kollar arasında 45 derecelik açılanma yaparak ' $Y$ ' harfine benzer görünüm oluşturduğu dikkati çekmiştir. Bu görünüm Aspergillus için tanı koydurucudur. Yapılan Periyodik Asit-Schiff (PAS) ve retikülin histokimyasal boyamaları ile Aspergillus organizmalarına ait hif yapıları belirgin olarak tesbit edilmiştir (Resim 2). Bu bulgular ışığında vakaya maksiller sinüs aspergillozisi tanısı konmuştur.

Hastaya 2 hafta boyunca vorikonazol kullanması üzere talimat verilmiştir.

Operasyondan sonra hastaya, 15 gün süreyle $2 \times 1$, $100 \mathrm{mg}$ oral vorikonazol kullandırarak antifungal ilaç tedavisi uygulanmıştır. Bu tedaviyi takiben 3 aylık periodlarla, toplam 6 ay boyunca yapılan kontrol muayenelerinde aspergillozis ile ilgili bulguya rastlanmamıştır.

\section{TARTIŞMA}

Sunulan vaka, maksiller sinüste gelişen ağrılı lezyonlarda aspergilloma inklüzyonlarının ayırıcı tanıdaki yerini vurgulamakta ve diş hekimliği alanında çalışan

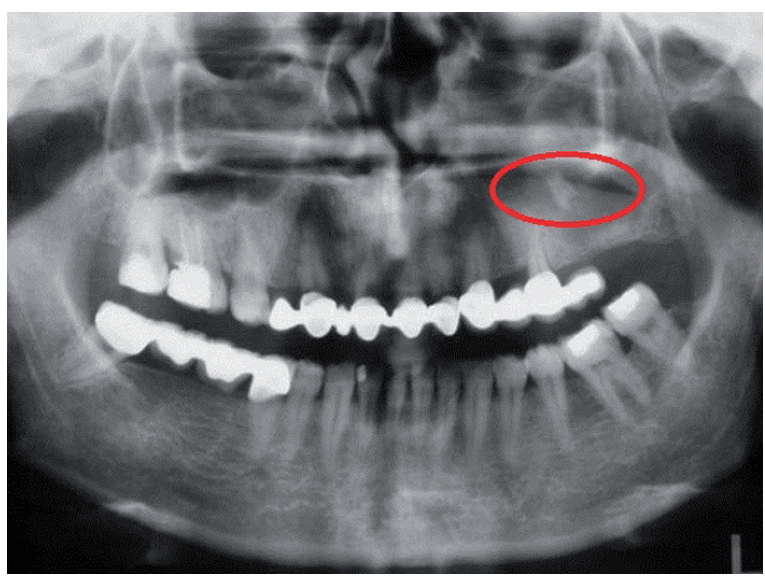

Resim 1. Panoramik radyografinin incelenmesinde, sol maksiller sinüs içerisinde sınırları iyi seçilemeyen, kırık köke ait olduğu düşünülen opasite izlenmektedir.

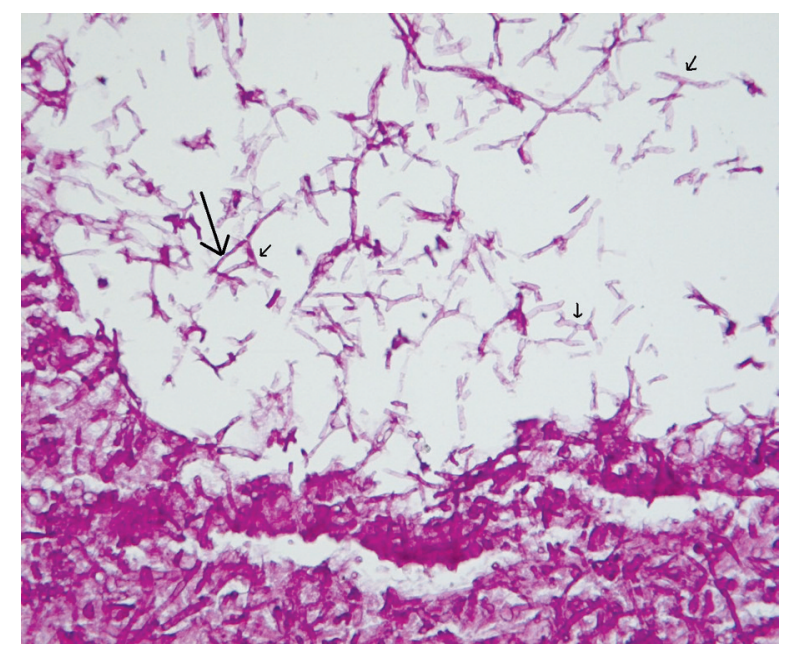

Resim 2. Dallanmalar gösteren Aspergillus organizmalarına ait hif yapıları izlenmektedir (Periyodik asit-Schiff boyasl; x400).

klinisyenlerde çok sık izlenmeyen bu antitite konusunda farkındalık yaratmayı amaçlamaktadır.

Paranazal sinüslerin aspergillozisinin hemen tüm semptomları diğer inflamatuar hastalıklar ile benzerlik göstermektedir. ${ }^{1}$ Genellikle burundan gelen periyodik pürülan akıntı, kötü koku, tipik olmayan baş ağrısı ve dişlerde ağrı şikayetleri izlenmektedir.,2,3

Maksiller sinüs aspergillozisi etyolojisinde pulpanın gangrenöz inflamasyonunun yanı sıra sinüs içine penetre olan dolgu maddesi, implant gibi yabancı cisimlerin de yer alabileceği bilinmektedir.4-6 Yapılan çalışmalarda Aspergillus fumigatus'un çoğalması için ortamda glikoz, nitrojen, sülfür, fosfor, potasyum, kalsiyum, magnezyum, demir ve çinko bulunması gerektiği ortaya konmuştur. ${ }^{2-4}$ Birçok araştırma belirtilen içeriğe sahip kanal dolgu materyallerinin bu mikroorganizmalar için uygun büyüme ortamı oluşturabilecek içeriğe sahip 
olduğunu ortaya koymuştur. Sinüse ait invaziv olmayan aspergillozisin kök kanalı simanları ya da dolgu materyallerinin sinüs içerisine taşması sonucu oluşabileceği ve çinkonun Aspergillus için büyüme faktörü olması nedeniyle çinko oksit temelli endodotik materyallerin enfeksiyonu arttırabileceği görüşü ortaya atılmıştır., ${ }^{4,5}$ Aspergillozis gelişimi için uygun koşullar aynı zamanda tedavi görmemiş periapikal değişiklikler ve alveoler sinüs fistüllerinde de mevcuttur. ${ }^{5}$

Sunulan vakanın panoramik radyografisinde kök kanalı içerisinde izlenen nispeten opak bölge ve daha önceki bir girişimde oluştuğu düşünülen kök kırığı, dişin kanal dolgusu içerdiğini telkin etmektedir. Ayrıca hastanın immün sisteminin almış olduğu kemoterapiye bağlı olarak baskılanmış olması vakada aspergillozis gelişimini kolaylaştıran faktörler olarak karşımıza çıkmaktadır.

Bu bilgiler ışığında ağrılı maksiller sinüs lezyonlarında hastanın daha önceden geçirmiş olduğu endodontik tedavilerinin, tedavi edilmemiş dişlerinin ve tıbbi geçmişinin sorgulanması ve mantar enfeksiyonu yönünden irdelenmesi önerilebilir. Dental materyallerin enfeksiyon için ortam oluşturabileceği akılda tutularak post-operatif olarak soketin iyi incelenmesi ve debridmanının yapılması ile yabancı cisimlerin maksiller sinüs ve yumuşak doku içine kaçması engellenerek yabancı cisim reaksiyonu, amalgam tattoo, sinüs aspergillozisi gibi birçok lezyon ve hastalığın gelişmesi önlenebilecektir.

\section{SONUÇ}

Spesifik bulgusu olmayan, klinik gidiş ve semptomlar açısından kronik sinüzit ile benzerlikler gösteren aspergillozis olgusuna dikkatli yaklaşılması ve gerekli görüldüğünde paranazal sinüslerden alınan dokuların patolojik incelemesinin yapılması önerilmektedir.

Çıkar çatışması: Yazarlar bu çalışmayla ilgili herhangi bir çıkar çatı̧̧malarının bulunmadığını bildirmişlerdir.

\section{KAYNAKLAR}

1. Bozkurt MK, Özçelik T, Saydam L, Kutluay L. Maksiller sinüste izole aspergillus enfeksiyonu: Olgu sunumu. Kulak Burun Boğaz İhtis Derg 2008;18:53-5.

2. Matjaz R, Jernej $P$, Mirela KR. Sinus maxillaris mycetoma of odontogenic origin: case report. Braz Dent J 2004;15:248-50.

3. Chao TK. Triple discrete fungus balls of the paranasal sinuses. Otolaryngol Head Neck Surg 2004;131:1014-5.
4. Khongkhunthian P, Reichart PA. Aspergillosis of the maxillary sinus as a complication of overfilling root canal material into the sinus: report of two cases. J Endod 2001;27:476-8.

5. Martins W, Ribeiro Rosa EA. Aspergillosis of the maxillary sinus: review and case report. Scand J Infect Dis 2004;36:758-61.

6. Taneja T, Saxena S, Aggarwal P, Reddy V. Fungal infections involving maxillary sinus-a difficult diagnostic task. J Clin Exp Dent 2011;3:72-6.

7. Hachem RY, Kontoyiannis DP, Chemaly RF, Jiang Y, Reitzel R, Raad I. Utility of galactomannan enzyme immunoassay and $(1,3)$ beta-Dglucan in diagnosis of invasive fungal infections: low sensitivity for Aspergillus fumigatus infection in hematologic malignancy patients. J Clin Microbiol 2009;47:129-33.

8. Chao TK. Triple discrete fungus balls of the paranasal sinuses. Otolaryngol Head Neck Surg 2004;131:1014-5.

\section{Isolated Aspergillosis of the left maxillary sinus: a case report}

\begin{abstract}
INTRODUCTION: Aspergillosis of the paranasal sinus is a rare, opportunistic infection mostly seen in immune-compromised patients. Among Aspergillus-related paranasal sinus infections, the most commonly isolated species is Aspergillus fumigatus.

CASE REPORT: Reported here is a case of aspergillosis in the left maxillary sinus in a patient who had taken chemotherapy due to adinocarcinoma in the salivary gland. The patient was complaining of severe pain; but the source of pain could not be detected in the clinical examination. On radiographic examination of a panoramic film taken from the patient, a radio-opaque substance in the left maxillary sinus, with indefinite borders, resembling a broken root was seen. A Caldwell-Luc operation was performed under local anesthesia, and the broken root together with infected tissues were removed and sent to the Oral Pathology Department for a histopathological examination. The diagnosis was aspergillosis. After the operation, the patient was instructed to use voriconazole for two weeks (100 mg, 2x1, peroral). Checked on each third month, no clinical sign of aspergillosis was found during the 6 months follow-up period.
\end{abstract}

Conclusion: Aspergillosis cases, usually, may be similar to chronic sinusitis and should be approached carefully. When in doubt, pathological examination of tissues from the paranasal sinuses is recommended.

KEYWORDS: Aspergillosis; maxillary sinus; mycoses; paranasal sinus diseases 